American Journal of Pharmacology and Toxicology 5 (1): 1-8, 2010

ISSN 1557-4962

(C) 2010 Science Publications

\title{
Mutagenic Screening of Crude Oil Fractions Using Modified Ames Test and Allium cepa (Linn) Assay
}

\author{
${ }^{1}$ Olufunsho Awodele, ${ }^{1}$ Alade Akintonwa, ${ }^{1}$ Sunday O. Olayemi, ${ }^{2}$ Chimezie Anyakora, \\ ${ }^{1}$ Gbenga O. Afolayan, ${ }^{1}$ Anthony T. Olofinnade, ${ }^{3}$ Stella I. Smith, \\ ${ }^{3}$ Emmanuel A. Omonigbehin and ${ }^{2}$ Herbert A.B. Coker \\ ${ }^{1}$ Department of Pharmacology, College of Medicine, University of Lagos, Nigeria \\ ${ }^{2}$ Department of Pharmaceutical Chemistry, Faculty of Pharmacy, University of Lagos, Nigeria \\ ${ }^{3}$ Departmentof Molecular Biology and Genetics, \\ Nigeria Institute of Medical Research, Yaba-Lagos, Nigeria
}

\begin{abstract}
Problem statement: Crude oil which may be broadly characterized as paraffinic or naphthenic is a complex mixture of alkanes, cycloalkanes and aromatic hydrocarbons. About 500,000 workers are employed in crude oil exploration and production worldwide. There have been reports of occupational exposure during drilling, pumping and transportation of crude oil, including maintenance of equipment used for these processes. Thus, skin tumors have been reported in mice after repeated application of the east Wilmington crude oil to their skin. Approach: It may thus be necessary to investigate the mutagenic potentials of crude oil fractions using a modified Ames test and internationally accepted Allium cepa (Linn) assay. The Allium cepa assay was done to determine the mean root length, mitotic index and chromosomal aberrations of the onions root grown in various concentrations of 5, 10 and $15 \% \mathrm{v} / \mathrm{v}$ crude oil, petrol, kerosene, engine oil and diesel in water. The modified Ames test which is a modification of the standard Ames test was done using E. coli (0157: $\mathrm{H} 7)$ that has the phenotypic characteristics of glucose and lactose fermentation, motile, urease negative, indole positive and citrate negative. Thus the alteration in normal biochemical characteristics was determined by inoculating the revertant strains produced by the organism after incubating with the crude oil fractions into the specified media to re-determine their biochemical characteristics. Results: The results obtained from the Allium cepa assay showed increasing root growth inhibition with increased concentration and decreasing mitotic index with increased concentration. Stickiness, Vagrant, Bridges and fragments, Bi-nuclei, C-mitosis, multi polar anaphase and anaphase with laggards chromosomal aberration were observed. The modified Ames test showed a remarkable alteration in the biochemical characteristics of E. coli $(0157: \mathrm{H} 7)$ by petrol and engine oil indicating mutagenicity. Conclusion: The results of the Ames test showed petrol and engine oil to demonstrate mutagenicity in bacteria, while, the Allium cepa assay showed mitodepressive effects of crude oil, petrol, engine oil, diesel and kerosene.
\end{abstract}

Key words: Crude oil, mutagenicity, Ames test, Allium cepa, E. coli

\section{INTRODUCTION}

Crude oil has been described as a complex mixture of over 6000 potentially different hydrocarbons and metals (Edwards, 1989). They may be broadly characterized as paraffinic or naphthenic that contains alkanes, cycloalkanes and aromatic hydrocarbon containing low percentages of sulfur, nitrogen, oxygen compounds and trace quantities of many other elements (International Agency for the Research on Cancer, 1989).
Worldwide, about 500,000 workers are employed in crude oil exploration and production (International Agency for the Research on Cancer, 1989). Accidental release of crude oil into aquatic environment, drilling, pumping and transportation of crude oil may all be potential source of human exposure.

In Nigeria, crude oil is predominantly found in the riverine areas and over the years the local population have used crude oil for various ailments such as gastrointestinal disorders, burns, foot rot, leg ulcers,

Corresponding Author: Olufunsho Awodele, Department of Pharmacology, College of Medicine, University of Lagos, Nigeria Tel: 234-802 3624044 
poisoning and witchcraft (Orisakwe et al., 1989). However, the crude oil fractions which include, Kerosene, Diesel oil, Petrol and Engine oil are products that are found and been used by people all over the country.

The long standing works of Leitch (1922; 1923; 1924) and Twort and Ing (1928), have documented the incidence of occupational tumors induced by various tars and oils in the Scottish oil shale industry, cotton spinning and incidence from other industries have also been shown by Scott (1922; 1923); Auld (1950) and Henry (1947).

The more recent study of Clark (1988) have also reported skin tumors developed in mice after application of east Wilmington crude oil to their skin. More so, an excess of lung cancer was seen in a large cohort of Japanese workers exposed to kerosene, diesel oil, crude petroleum and mineral oil.

Thus, the research of (Ashby et al., 1978; Bryan et al., 1970; Miller, 1985; Reuber, 1978), have demonstrated that most substances which have been found to be mutagenic also seem to be carcinogenic. Furthermore, Ames et al. (1973) have demonstrated that mutagens cause cancer by somatic mutation.

Contrary to the above findings and understanding, the International agency for research on cancer in 1989 has reported a negative result obtained with Kerosene and Diesel oil when investigated for their ability to induce gene mutation using Salmonella typhimurium TA 98 and TA 100.

This present study used both modified Ames test which is a bacteria mutation assay and Allium cepa (Linn) model which is a plant mutation assay to investigate the mutagenic potentials of crude oil, kerosene, petrol, diesel oil and engine oil.

\section{MATERIALS AND METHODS}

Modified Ames test: This is a modification of the standard Ames assay as described by Ames et al. (1975).

Crude oil fractions: Crude oil fractions Kerosene $^{\mathrm{R}}$, Petrol $^{\mathrm{R}}$, Diesel ${ }^{\mathrm{R}}$, Engine oil ${ }^{\mathrm{R}}$ ) were obtained from Total Filing Station Isaga Road, Surulere-Lagos and Crude oil was obtained from Shell Petroleum Development Company (SPDC) Port Harcourt, Nigeria.

Media preparation: The various media that were used for this assay are MacConkey agar, Kliger Iron Agar (KIA), Motility Indole Urea (MIU), Simmon citrate, Brain heart infusion agar, Nutrient agar and Brain heart infusion broth. The preparation of these media were in accordance with the procedure of the LAB $\mathrm{M}^{\mathrm{TM}}$ (Topley Home, 52 Washlane Bury, Lancanshire, BL96AU, UK).

Preparation of the rat microsomal liver enzyme (S9): Two Sprague-Dawley rats weighing about $180 \mathrm{~g}$ each were obtained from the animal house of the College of Medicine of the University of Lagos. The rats were injected intra-peritoneally with $10 \mathrm{mg} \mathrm{kg}^{-1}$ of Phenobarbitone for three days to induce the liver microsomal enzymes as suggested by Maron and Ames (1984). After the third day, the animals were sacrificed and the liver was extracted aseptically and then macerated using a prior sterilized mortar and pestle. To every $1 \mathrm{~g}$ of the macerated liver, $5 \mathrm{~mL}$ of $1.65 \mathrm{M} \mathrm{KCl}$ solution was added. The resulting solution was centrifuged (1200 revolutions $\left.\mathrm{min}^{-1}\right)$ and the supernatant was filtered using a sterile membrane filter to obtain the rat microsomal enzyme.

The S9 Mix: The S9 mix was freshly prepared using the method of Maron and Ames (1984). Thus, $20 \mathrm{~mL}$ of S9 mix contains $2 \mathrm{~mL}$ of rat liver enzyme, $10 \mathrm{~mL}$ of $0.2 \mathrm{M}$ phosphate buffer at $\mathrm{pH}$ of $7.4,5.6 \mathrm{~mL}$ of distilled water, $1 \mathrm{~mL}$ of $80 \mathrm{mM}$ NADP sodium salt hydrate, $1 \mathrm{~mL}$ of $120 \mathrm{mM}$ Glucose-6-phosphate and $0.4 \mathrm{~mL}$ of potassium and magnesium salts solution. The mixture was stirred properly before $2 \mathrm{~mL}$ of the rat liver enzyme (S9) was added.

Inoculation: The MacConkey agar plate was subcultured with one strain of E. coli [0157:H7] obtained from the Genetics Department of the Nigerian Institute of Medical Research, Yaba-Lagos (NIMR) and incubated at $37^{\circ} \mathrm{C}$ for $24 \mathrm{~h}$ to obtain discrete colonies. Thus, the discrete colonies of the organism were re-sub cultured into new MacConkey plates and incubated at $37^{\circ} \mathrm{C}$ for $24 \mathrm{~h}$ to ensure the use of standard strain of the organism and not contaminants. This organism has biochemical characteristics of fructose and glucose fermenting, motile, urease negative, indole positive and citrate negative.

Bacteria mutation assay: The assay was performed using E. coli (0157: H7) which have been grown on MacConkey plates to obtain discrete colonies. The experiment was performed in the presence and absence of metabolic activation of the rat liver enzyme. The fraction of the liver enzyme (S9) was used at a concentration of $10 \%(\mathrm{v} / \mathrm{v})$ in the S9 mix. The S9 mix was freshly prepared for the experiment according to the method of Maron and Ames (1984). Test agents and positive control were tested with this strain of organism 
for this experiment, Ethidium bromide which is a known intercalating agent was used as the positive control. Fresh culture of tested strain obtained from MacConkey plate was inoculated and grown in the brain heart infusion broth. The brain heart infusion broth containing the organism was incubated for 10$12 \mathrm{~h}$ at $37^{\circ} \mathrm{C}$ in order to ensure adequate aeration. $0.1 \mathrm{~mL}$ of the brain heart infusion broth that contains the organism was mixed with $0.5 \mathrm{~mL}$ S9 mix and $0.1 \mathrm{~mL}$ of the test sample. The mixture was incubated at $37^{\circ} \mathrm{C}$ for $72 \mathrm{~h}$ and later seeded into the brain heart infusion agar plates, while the other portion without S9 was also seeded on other brain heart infusion agar plates. The plates were incubated at $37^{\circ} \mathrm{C}$ for $24 \mathrm{~h}$. The revertant strains produced were inoculated into the KIA, MIU and Citrate agar to re-examine the organism's biochemical characteristics. An alteration in at least 3 biochemical characteristics out of the 7 biochemical characteristics will be taken as the bench mark for mutagenicity. However, alteration in biochemical characteristics less than 3 may illustrates a weak mutagenicity or no mutagenicity.

Allium cepa (Linn) assay: The Allium test provides a rapid screening procedure for chemicals and environmental agents which may represent environmental hazards. Root growth inhibition and adverse effects on chromosomes provide an indication of likely toxicity.

Healthy equal sizes of common onions were obtained from Bariga local market of Lagos, Nigeria. The dried outer scales were carefully removed leaving the ring of the root primodial intact (Fiskesjo, 1985). Five onion bulbs were utilized for each concentration of: 5, 10 and $15 \%$ Crude oil fractions.

Tap water of good quality was used for negative control. The base of each of the onion bulbs was grown on each of the concentration of the environmental agents inside a $30 \mathrm{~mL}$ beaker and placed away from sunlight for 4 days after which the root length was measured.

Root growth inhibition test: The toxicity assay was performed as a $96 \mathrm{~h}$ semi-static exposure test and three (3) concentrations of the test samples were used. Every $24 \mathrm{~h}$ the test solutions were replaced by fresh solutions. The test solutions were used at room temperature and at the termination of the exposure, the length of the root bundles were measured and their mean \pm SE were calculated

Microscopic analysis: The root tips at a length of $10 \mathrm{~mm}$ were cut off and fixed in Acid: Alcohol solution
(1:3) by heating for $5 \mathrm{~min}$ at $50^{\circ} \mathrm{C}$. There after the terminal root tips (1-2 $\mathrm{mm})$ were cut off and squashed on the slide and stained with Orcein solution for 10 min. The cover slip was then carefully lowered on the stained area to avoid air bubble and slides were carefully dampened with the use of a filter paper to remove the excess stain. The cover slip was fixed carefully to the slide with nail varnish.

The slides were examined under the microscope to determine the mitotic index and chromosomal aberrations. The Mitotic Index (MI) was determined by counting all stages of mitotic cells out of 1000 cells:

$$
\text { Mitotic index }=\frac{\text { No. of dividing cells }}{\text { Total number of cells analyzed }} \times 1000
$$

The slides were examined from right to left; up and down and the first 100 Metaphase, Anaphase and Teleophase cells were scored for aberrations.

\section{RESULTS}

Modified Ames test: Table 1 shows the results of crude oil fractions to modified Ames test. The results revealed the normal biochemical characteristics of $E$. coli (0157:H7) to be Citrate and Urease negative, Indole positive, Glucose and fructose fermenting, Motile and produced carbon dioxide gas. Ethidium bromide which is the positive control showed an alteration in some of these normal biochemical characteristics of the organism. It produced revertant strain that showed positive results to Citrate and Urease, not able to ferment fructose, not motile and produced hydrogen sulphide gas. The Table 1 results further showed Engine oil ${ }^{\mathrm{R}}$, Petrol ${ }^{\mathrm{R}}$ and Crude oil to alter the organism characteristics to urease positive. A positive result to Citrate was also obtained with the revertant strains produced by Engine oil ${ }^{\mathrm{R}}$ and Petrol $^{\mathrm{R}}$. The results produced by the revertant strains of Kerosene ${ }^{\mathrm{R}}$ and Diesel $^{\mathrm{R}}$ showed gas production and indole positive respectively. However, the organism produced hydrogen sulphide gas with Engine oil ${ }^{\mathrm{R}}$, Petrol ${ }^{\mathrm{R}}$, Kerosene $^{R}$ and Crude oil. The results above also showed that Diesel ${ }^{\mathrm{R}}$ altered the fructose fermentation characteristics of the organism to be non fructose fermenting.

Figure 1 showed revertant strain producing hydrogen sulphide in KIA, there was also revertant strain that altered the butt and did not change the normal orange color of the slant indicating lost of ability to ferment fructose. There was color alteration from green to blue in Simmon citrate media after inoculating with revertant strain indicating a positive 
result to citrate utilization. The MIU also showed absence of red ring above the media upon the addition of kovarsc reagent after inoculating with revertant strain indicating negative result to indole production. There was also color alteration of MIU from yellow to pink after the inoculation of revertant strain showing the utilization of urease.

Allium cepa (Linn) model: The results on Table 2 showed the Cytotoxic and Root growth inhibitory effects of various concentrations of Engine oil, Crude oil and Kerosene on Allium cepa. The results on Engine oil and Crude oil revealed a concentration dependent decrease in mitotic index as the concentration of the crude fractions increases. It also showed a significant $(\mathrm{p}<0.05)$ decreased in mean root length as the concentration increases. Further more, the results showed the occurrence of Stickness, Bridges and fragments, C-mitosis and Vagrant Chromosomal aberrations. However, Allium cepa did not produce any root growth in the various concentrations of the Kerosene used.

The results on Table 3 showed the Cytotoxic and Root growth inhibitory effects of various concentrations of Diesel and Petrol on Allium cepa. The results on petrol revealed a concentration dependent decrease in mitotic index as the concentration of the petrol increases. It also showed a significant $(\mathrm{p}<0.05)$ decreased in mean root length as the concentration increases, except for the highest concentration (15\%) which produced no root growth in the Allium cepa. Further more, the results showed the occurrence of Stickness, Bridges and fragments, C-mitosis and Vagrant Chromosomal aberrations. However, Allium cepa did not produce any root growth in the various concentrations of the Diesel used.
Figure 2 showed the various aberrations observed in the root cells of the Allium cepa. Most of the aberrations were observed at the Anaphase stage of mitotic division. Some of the chromosomes were linked together instead of separating to the poles forming bridges and fragments. There was also a lag observed in the chromosomal migration to the poles (Fig. 3).

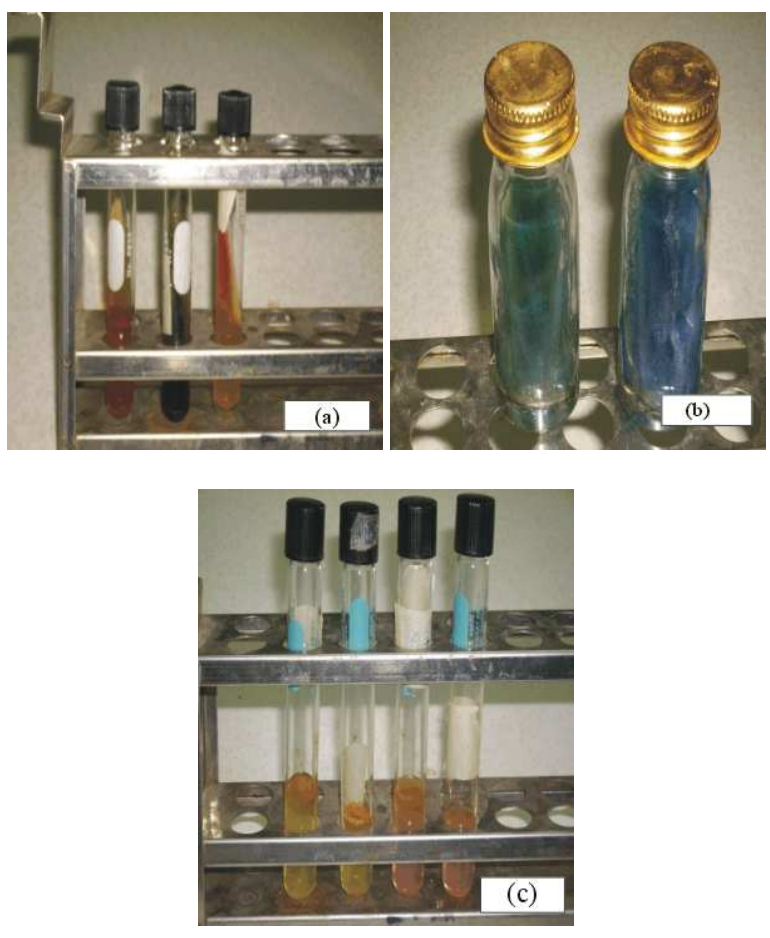

Fig. 1: Appearance of KIA, MIU and Simmon citrate after inoculating with revertant strains of $E$. coli 0157:H7. (a) Kliger Iron Agar (KIA) media; (b) Simmon citrate media; (c) Motility Indole Urea (MIU) media

Table 1: Normal biochemical characteristics of E. coli $(0157: \mathrm{H} 7)$ and the biochemical characteristics of $E$. coli $(0157: \mathrm{H} 7)$ after treatment with crude oil fractions and ethidium bromide

\begin{tabular}{|c|c|c|c|c|c|c|c|c|}
\hline \multirow[b]{2}{*}{ Strain/crude oil fractions } & \multicolumn{4}{|c|}{ Kliger Iron Agar (KIA) } & \multicolumn{3}{|c|}{ Motility Indole Urea (MIU) } & \multirow[b]{2}{*}{ Simmons citrate } \\
\hline & Butt & Slant & $\mathrm{H}_{2} \mathrm{~S}$ & Gas & Motility & Indole & Urease & \\
\hline \multicolumn{9}{|c|}{$\begin{array}{l}\text { Characteristics of Escherichia coli [0157:H7] } \\
\text { [e }\end{array}$} \\
\hline 0517:H7 & GF & LF & - & + & + & + & - & - \\
\hline \multicolumn{9}{|c|}{ Characteristics of revertant strains of $E$. coli $[0157: \mathrm{H} 7]$ after treatment with the crude oil fractions and Ethidium bromide } \\
\hline Engine oil ${ }^{\circledR}$ & GF & $\mathrm{LF}$ & $+^{\mathrm{f}}$ & + & + & + & $+t^{\mathrm{b}}$ & $t^{\mathrm{a}}$ \\
\hline Diesel $^{\circledR}$ & GF & $\mathrm{NLF}^{\mathrm{g}}$ & - & + & + & $-{ }^{c}$ & - & - \\
\hline Petrol $^{\circledR}$ & $\mathrm{GF}$ & $\mathrm{LF}$ & $++^{\mathrm{f}}$ & + & + & + & $t^{\mathrm{b}}$ & $t^{\mathrm{a}}$ \\
\hline Kerosene $^{\circledR}$ & $\mathrm{GF}$ & LF & $+{ }^{\mathrm{f}}$ & $-{ }^{\mathrm{e}}$ & + & + & - & - \\
\hline Crude oil ${ }^{\circledR}$ & $\mathrm{GF}$ & LF & $+^{\mathrm{f}}$ & + & + & + & $t^{\mathrm{b}}$ & - \\
\hline Ethidium Bromide & $\mathrm{GF}$ & $\mathrm{NLF}^{\mathrm{g}}$ & $+{ }^{\mathrm{f}}$ & + & $-{ }^{\mathrm{d}}$ & + & $+{ }^{\mathrm{b}}$ & $t^{\mathrm{a}}$ \\
\hline
\end{tabular}

Key: GF $=$ Glucose fermenting, $\mathrm{LF}=$ Lactose fermenting, NLF $=$ Non lactose fermenting $+=$ Positive, $-=$ Negative ${ }^{\mathrm{a}}:$ Citrate positive, ${ }^{\mathrm{b}}:$ Urease positive, ${ }^{\mathrm{c}}$ : Indole negative, ${ }^{\mathrm{d}}$ : Not motile, ${ }^{\mathrm{e}}$ : Produced gas, ${ }^{\mathrm{f}}$ : Produced hydrogen sulphide gas, ${ }^{\mathrm{g}}$ : Non lactose fermenting. 
Am. J. Pharm. \& Toxicol., 5 (1): 1-8, 2010

Table 2: Effects of various concentrations of crude oil fractions on the cytology and root growth of Allium cepa Crude oil fractions

\begin{tabular}{|c|c|c|c|c|c|c|c|c|}
\hline \multirow[b]{2}{*}{ Treatment conc. $(\%)$} & \multicolumn{3}{|c|}{ Phenotypic indices } & \multicolumn{5}{|c|}{ Chromosome aberrations } \\
\hline & $\begin{array}{l}\text { No of dividing } \\
\text { cells }\end{array}$ & MI & $\begin{array}{l}\text { Mean root } \\
\text { length } \pm \mathrm{SE}\end{array}$ & Stickiness & $\begin{array}{l}\text { Multipolar } \\
\text { anaphase }\end{array}$ & $\begin{array}{l}\text { Bridges and } \\
\text { fragments }\end{array}$ & c-mitosis & Vagrant \\
\hline \multicolumn{9}{|l|}{ Engine oil } \\
\hline 0 & 23 & 46 & $4.33 \pm 0.14$ & 0 & 0 & 0 & 0 & 0 \\
\hline 5 & 20 & 40 & $0.85 \pm 0.18^{\mathrm{a}}$ & 5 & 0 & 1 & 1 & 5 \\
\hline 10 & 12 & 24 & $0.45 \pm 0.04^{\mathrm{a}}$ & 3 & 1 & 3 & 0 & 3 \\
\hline 15 & 10 & 20 & $0.10 \pm 0.02^{\mathrm{a}}$ & 4 & 1 & 0 & 0 & 1 \\
\hline \multicolumn{9}{|l|}{ Crude oil } \\
\hline 0 & 23 & 46 & $4.33 \pm 0.14$ & 0 & 0 & 0 & 0 & 0 \\
\hline 5 & 23 & 46 & $0.90 \pm 0.28^{\mathrm{a}}$ & 12 & 1 & 0 & 4 & 6 \\
\hline 10 & 14 & 28 & $0.16 \pm 0.03^{\mathrm{a}}$ & 4 & 0 & 0 & 0 & 4 \\
\hline 15 & NIL & NIL & NIL & NIL & NIL & NIL & NIL & NIL \\
\hline \multicolumn{9}{|l|}{ Kerosine } \\
\hline 0 & 23 & 46 & $4.33 \pm 0.14$ & 0 & 0 & 0 & 0 & 0 \\
\hline 5 & NIL & NIL & NIL & NIL & NIL & NIL & NIL & NIL \\
\hline 10 & NIL & NIL & NIL & NIL & NIL & NIL & NIL & NIL \\
\hline 15 & NIL & NIL & NIL & NIL & NIL & NIL & NIL & NIL \\
\hline
\end{tabular}

Table 3: Effects of various concentrations of crude oil fractions on the cytology and root growth of Allium cepa

Crude oil fractions

\begin{tabular}{|c|c|c|c|c|c|c|c|c|}
\hline \multirow[b]{2}{*}{$\begin{array}{l}\text { Treatment } \\
\text { conc. }(\%)\end{array}$} & \multicolumn{3}{|c|}{ Phenotypic indices } & \multicolumn{5}{|c|}{ Chromosome aberrations } \\
\hline & $\begin{array}{l}\text { No. of } \\
\text { dividing cells }\end{array}$ & MI & $\begin{array}{l}\text { Mean root } \\
\text { length } \pm \mathrm{SE}\end{array}$ & Stickiness & $\begin{array}{l}\text { Multipolar } \\
\text { anaphase }\end{array}$ & $\begin{array}{l}\text { Bridges and } \\
\text { fragments }\end{array}$ & c-mitosis & Vagrant \\
\hline \multicolumn{9}{|l|}{ Diesel: } \\
\hline 0 & 23 & 46 & $4.33 \pm 0.14$ & 0 & 0 & 0 & 0 & 0 \\
\hline 5 & NIL & NIL & NIL & NIL & NIL & NIL & NIL & NIL \\
\hline 10 & NIL & NIL & NIL & NIL & NIL & NIL & NIL & NIL \\
\hline 15 & NIL & NIL & NIL & NIL & NIL & NIL & NIL & NIL \\
\hline \multicolumn{9}{|l|}{ Petrol: } \\
\hline 0 & 23 & 46 & $4.33 \pm 0.14$ & 0 & 0 & 0 & 0 & 0 \\
\hline 5 & 15 & 30 & $0.40 \pm 0.21^{\mathrm{a}}$ & 3 & 0 & 2 & 0 & 3 \\
\hline 10 & 8 & 16 & $0.20 \pm 0.08^{\mathrm{a}}$ & 4 & 0 & 1 & 0 & 2 \\
\hline 15 & NIL & NIL & NIL & NIL & NIL & NIL & NIL & NIL \\
\hline
\end{tabular}

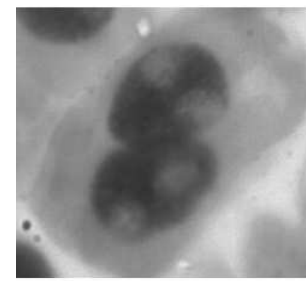

Bi-nulei

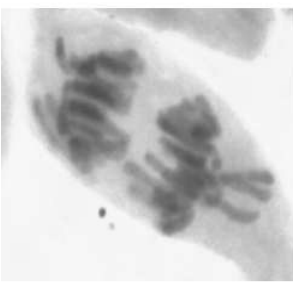

Anaphase with laggards

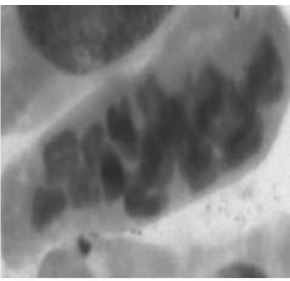

C-mitosis

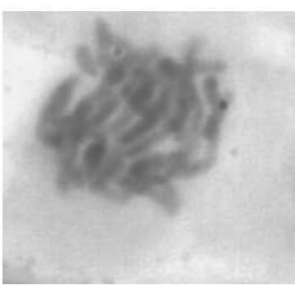

Bridges and fragments
Fig. 2: Aberrations at various stages of mitotic division in cells of Allium cepa treated with the mixture of different crude oil fractions. Mag. $\times 1000$. Stain: Orcein

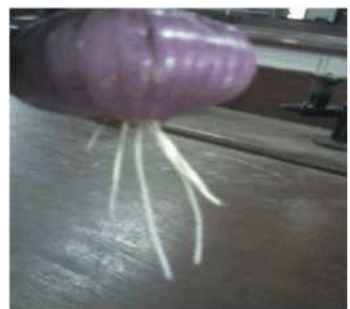

Control

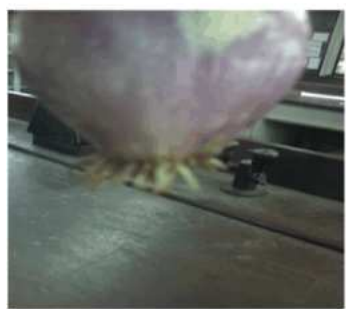

Treated

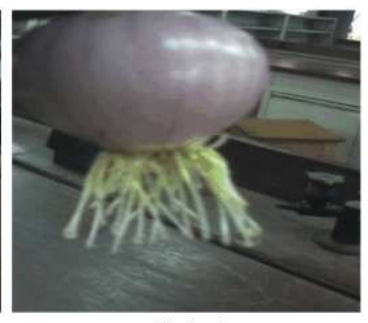

Control

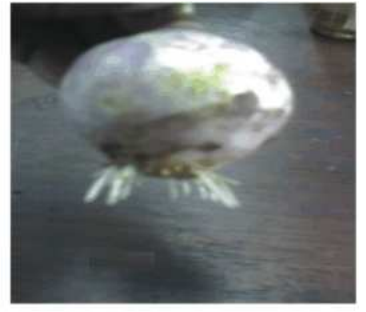

Treated
Fig. 3: Photograph of Allium cepa samples of both treated and control groups 


\section{DISCUSSION}

Escherichia coli 0157: H7 was obtained from the Nigeria institute of Medical Research, Yaba-Lagos. The organism was subjected to the method of identification of Enterobacteriaceae as described by Edwards and Ewing (1972); Cowan (1973). The organism was found not to utilize citrate as its only source of carbon and a green coloration of the Simmon's citrate agar was obtained. However, a bright blue color of Simmon's citrate agar indicates positive results to citrate. The organism was also found not to produce Urease as it is unable to break down urea to ammonia and carbon dioxide. Thus, a yellow color of Motility indole urea agar indicates negative results while Red/purple indicates positive results. Furthermore, the organism was observed to break down amino acid tryptophan with the release of indole. Thus, a red surface layer upon the addition of Kovac's reagent indicates positive result to indole. While a yellow coloration of the Motility indole urea indicates negative results to indole. The organism was also observed to have a strand of movement in the motility indole urea agar, which showed the organism to be motile. Furthermore, an upward shift of the Kliger iron agar from the bottom of the tube was observed which reflected carbon dioxide production. The organism demonstrated the ability to ferment both glucose and fructose with the alteration of the color of the Kliger iron agar from orange to yellow.

The studies of Tixier-Boichard (2002); Kammenga (2007); Deepa et al. (2008) and Sambandan et al. (2008) have all adduced the fact that phenotypic expression is always a function of genotype and the environment. Therefore, any alteration in the above mentioned normal biochemical characteristics of the organism may be due to alteration of the genetic material (DNA).

Based on the above statement of fact, this study therefore set a bench mark for mutagenicity to be any agent that altered at least 3 normal biochemical characteristics of the organism.

The results obtained from this present study that used Modified Ames test and Allium cepa (Linn) assay to investigate the mutagenic potentials of Crude oil, Kerosene $^{R}$, Petrol ${ }^{R}$, Diesel ${ }^{R}$ and Engine oil ${ }^{R}$ have shown that Engine oil ${ }^{R}$ and Petrol ${ }^{R}$ altered not less than 3 biochemical characteristics of the normal biochemical characteristics of the E. coli thus suggesting them to have mutagenic ability. These findings may be substantiated with the works of Nylander et al. (1978) and Magnusson et al. (2000) that showed petrol to be mutagenic in Drosophila melanogaster and to contain high level of Polycyclic aromatic hydrocarbon that gave it a significant mutagenic test in Salmonella typhimurium TA98 and TA100. However, the other crude oil fractions, Kerosene $^{\mathrm{R}}$, Diesel ${ }^{\mathrm{R}}$ and Crude oil did not alter up to three (3) biochemical characteristics of the normal characteristics of the organism. Diesel altered the ability of the organism to ferment lactose and showed negative result to indole whereas kerosene made the organism to produce hydrogen sulphide but not carbon dioxide gas. Crude oil on the other hand altered the normal biochemical characteristics of the organism and thus produced a strain of organism that was positive to urease and produced hydrogen sulphide gas. These alterations produced by Crude oil, Diesel ${ }^{\mathrm{R}}$ and Kerosene $^{\mathrm{R}}$ may suggest their non mutagenic or mild mutagenic properties. These results may corroborate some of the past studies that showed kerosene ${ }^{R}$ to produced negative result to Ames assay using Salmonella typhimurium of TA98 and TA100 (International Agency for the Research on Cancer, 1989) and Diesel ${ }^{R}$ to have inadequate evidence to be classified as human carcinogen and thus classified to be non genotoxic (Bebarta and Wilt, 2004).

The results obtained from the Allium cepa Linn assay showed Diesel $^{\mathrm{R}}$ and Kerosene ${ }^{\mathrm{R}}$ to absolutely inhibit the growth of Allium cepa at all concentration. This could imply the pronounced toxicity of these agents to the root growth of Allium cepa. More so, the results obtained from Crude oil, Petrol ${ }^{\mathrm{R}}$ and Engine oil ${ }^{\mathrm{R}}$ showed a concentration dependent decrease in root growth. As the concentration of the crude oil fractions increases the root length of Allium cepa decreases. The results also showed mitotic index to decrease as the concentration increases which may suggest the mitodepressive effect of these crude oil fractions. The microscopic examination also revealed chromosomal damages such as stickness, multipolar anaphase, Bridges and fragment and vagrant aberrations. These aberrations may be due to the effect of the crude oil fractions on the mitotic spindles.

Drawing inferences from these two models, it may then be concluded that Engine oil and Petrol have shown high level of mutagenicity however, crude oil and its other fractions may be termed to have mild or non mutagenic potentials.

\section{CONCLUSION}

It has been established from these findings that Petrol and Engine oil demonstrated mutagenic characteristics. More so, all crude oil fractions have demonstrated mitodepressive effects and disturbances of mitotic cell division. 
However, these in vitro results may initiate an extensive in vivo study so as to ascertain these findings. Thus, our research team is presently investigating the mutagenic potential of crude oil using a micronucleus assay.

\section{REFERENCES}

Ames, B.N., J. McCann and E. Yamasaki, 1975. Methods for detecting carcinogens and mutagens with the Salmonella/mammalian microsome mutagenicity test. Mutat. Res., 31: 347-364. http://www.ncbi.nlm.nih.gov/pubmed/768755

Ames, B.N., W.E. Dursten, E. Yamasaki and F.W. Lee, 1973. Carcinogens are mutagens: A simple test system combining liver homogenates for activation and bacteria for detection. Proc. Natl. Acad. Sci., USA., $\quad 70$ : 2281-2285. http://www.pnas.org/content/70/8/2281.abstract

Ashby J., J.A. Style, D. Anderson and D. Paton, 1978. Saccharrin: An epigenic carcinogen/mutagen. Food Cosmet Toxicol., 16: 95-103. http://www.ncbi.nlm.nih.gov/pubmed/352864

Auld, S.J.M., 1950. Environmental cancer and petroleum. Inst. Petrol, 36: 235.

Bebarta, V. and C. De Wilt, 2004. Miscellaneous hydrocarbon solvents. Clin. Occup. Environ. Med., $4: 455-459$. http://www.ncbi.nlm.nih.gov/pubmed/15325316

Bryan, G.T., E. Erturk and O. Yoshida, 1970. Production of urinary bladder carcinomas in mice by sodium saccharin. Science, 168: 1238-1240. http://www.ncbi.nlm.nih.gov/pubmed/5442712

Clark, C.R., 1988. Comparative dermal carcinogenesis of shale and petroleum derived distillates. Toxicol. Ind. Health, 4: 11-22. http://www.ncbi.nlm.nih.gov/pubmed/3388444

Cowan, S.T., 1973. Identification of medical Bacteria. In: Cowan and Steel's Manual for the Identification of Medical Bacteria, Barrow, G.I. (Ed.)., 3rd Edn., Cambridge University Press, Cambridge, ISBN: 13: 9780521543286.

Edwards, C.W., 1989. Toxicology of oil field waste hazards to livestock associated with the petroleum industry. Vet. Clin. N. Am., 5: 363-374. http://thorax.bmj.com/cgi/content/abstract/44/7/533

Edwards, P.R. and W.H. Ewing, 1972. Identification of Enterobacteriaceae. 3rd Edn., Burgess Publishing Co., Minneapolis, Minn, pp: 362. http://orton.catie.ac.cr/cgibin/wxis.exe/?IsisScript=HAG.xis\&method=post\& formato $=2 \&$ cantidad $=1 \&$ expresion $=m f n=009938$
Fiskesjo, G., 1985. The Allium test as a standard in environmental monitoring. Hereditas, 102: 99-112. http://www.ncbi.nlm.nih.gov/pubmed/3988545

Henry, S.A., 1947. Occupational cutaneous cancer attributable to certain chemicals in industry. $\mathrm{Br}$. Med. Bull., 4: 381-401. http://bmb.oxfordjournals.org/cgi/pdf_extract/4/5$6 / 389$

International Agency for the Research on Cancer, (IARC), 1989. Occupational exposures in petroleum refining. Crude oil and major petroleum fuels. IARC monographs on the evaluation of carcinogenic risks to humans.

http://apps.who.int/bookorders/anglais/detart1.jsp?s esslan $=1 \&$ codlan $=1 \& \operatorname{codcol}=72 \& \operatorname{cod} c \mathrm{ch}=45$

Kammenga, J.E., 2007. Genetic variation and genomeenvironment interaction in $\mathrm{C}$ elegans. Proceeding of the 14th Benelux Congress of Zoology, (BCZ'07), Amsterdam, The Netherlands, pp: 1-2. http://www.nem.wur.nl/UK/Research/Ecogenomics/

Leitch, A., 1922. Parraffin cancer and its experimental production. Brit. Med. J., 2: 1104. http://www.jstor.org/pss/20421874

Leitch, A., 1923. The experimental inquiry into the causes of cancer. Br. Med. J., 4: 210-210. http://www.pubmedcentral.nih.gov/articlerender.fc gi? artid=2317302

Leitch, A., 1924. Mule spinners cancer and mineral oils. Br. Med. J., 2: 941. http://www.jstor.org/pss/20438450

Magnusson, R., C. Nilsson, K. Andersson, B. Andersson and R. Gieling et al., 2000. Determination of chemical composition and mutagenicity in particles from chains saw exhaust. Experimental set up, stability and results from two different fuels. Environ. Technol., 21: 819-829. http://cat.inist.fr/?aModele $=$ afficheN\&cpsidt $=1395$ 686

Maron, C. and B.N. Ames, 1984. Revised methods for the Salmonella Mutagenicity Test. In: Handbook of Mutagenicity Test Procedures, Kilbey, B.J., M. Legator, W. Nichols and C. Ramel (Eds.). Elsevier Science Publishers, Amsterdam, Oxford, New York, ISBN: 0444805192, pp: 93-141.

Miller, M., 1985. Danger! Additives at Work. 1st Edn., London Food Commission, London.

Nylander, P.O., H. Olofsson, B. Rasmuson and H. Svalilin, 1978. Mutagenic effects of petrol in Drosophila melonogaster. Effects of benzene and 1, 2dichloroethane. Mutat. Res., 57: 163-167. http://www.ncbi.nlm.nih.gov/pubmed/96337 
Orisakwe, O.E., A.A Njan, O.J Afonne, D.D. Akumka, V.N. Orish and O.O. Udemezue, 1989. Investigation into the nephrotoxicity of Nigerian Bonny light crude oil in Albino rats. Int. J. Environ. Res. Public Health, 1: 106-110. http://www.ncbi.nlm.nih.gov/pubmed/16696185

Reuber, M.D., 1978. Carcinogenicity of saccharrin. Enviorn. Health Perspect., 25: 173-200. http://www.pubmedcentral.nih.gov/articlerender.fc gi?artid=1637197

Sambandan, D., M.A. Carbone, R.H. Robert Auhoit and F.C. Trady Mackay, 2008. Phenotypic plasticity and Genotype by Environment interaction for olfactory behavior in Drosophila melanogaster. Genetics, $\quad 179$ : 1079-1088. http://www.pubmedcentral.nih.gov/articlerender.fc gi? artid=2429861

Scott, A., 1922. On the occupational cancer of the paraffin and oil workers of the Scottish shale oil industry. Br. Med. J., 2: 1108-1109.
Scott, A., 1923. The occupational dermatoses of the paraffin workers of the Scottish shale oil industry, with a description of a system adopted and results obtained at the periodic examination of these workmen. Proceeding of the 8th Scientific Reports Imp-Cancer Research Foundation, (SRICRF'23), London, pp: 85-142.

Tixier-Boichard, M., 2002. From phenotype to genotype: Major genes in chickens. World's Poult. Sci. $\quad$ J., 58: 65-76. http://direct.bl.uk/bld/PlaceOrder.do?UIN=111622 $681 \&$ ETOC $=$ RN\& from $=$ searchengine

Twort, C.C. and H.R. Ing, 1928. Mule spinners cancer and mineral oils. Lancet, 214: 752.

Kindly find the following corrections made on the article titled: Mutagenic Screening of Crude Oil Fractions Using Modified Ames Test and Allium cepa (Linn) Assay

\section{Authors list arrangement \\ ${ }^{1}$ Olufunsho Awodele, ${ }^{1}$ Alade Akintonwa, ${ }^{1}$ Sunday O. Olayemi, ${ }^{2}$ Chimezie \\ Anyakora, ${ }^{1}$ Gbenga O. Afolayan, ${ }^{1}$ Anthony T. Olofinnade, ${ }^{3}$ Stella I. Smith, ${ }^{3}$ Emmanuel A. Omonigbehin and ${ }^{2}$ Herbert A.B. Coker}

\section{INTRODUCTION}

There must be bracket close after ( IARC, 1989)

\section{RESULTS}

Table 1 title should be E.coli (0157:H7) and not FO157:H7 